(v 17 cases with left atrial isomerism). ${ }^{3}$ It is thought that the fetal bradycardia and/or structural cardiac lesions contribute to low cardiac output and consequent hydrops, with a dismal prognosis. ${ }^{3-5}$

After browsing the literature, I remain perplexed that right atrial isomerism is detected so infrequently in utero, given the typical severity of its lesions. However, the current data from fetal echocardiography centres indicate that left atrial isomerism accounts for many more cases of fetal hydrops than right atrial isomerism. Apparently, it is the combination of heart block with structural cardiac defects which puts the fetus at high risk for hydrops, as the prognosis is much better for heart block without structural abnormalities. ${ }^{34}$

COLIN K PHOON Division of Pediatric Cardiology, University of California Medical Center, San Francisco, CA 94143-0544, USA

1 Stephenson T, Zuccollo J, Mohajer M. Diagnosis and management of non-immune hydrops in the newborn. Arch Dis Child 1994; 70: F151-4.

2 Phoon CK, Neill CA. Asplenia syndrome: insight into embryology through an analysis of cardiac and extracardiac malformations. Am $\mathcal{f}$ Cardiol 1994; 73: 581-7.

3 Schmidt KG, Ulmer HE, Silverman NH, fetal complete atrioventricular block: a center experience. 7 Am Coll Cardiol 1991; 17: $1360-6$.

4 Brook MM, Silverman NH, Villegas M. Cardiac ultrasonography in structural abnormalities and arrhythmias. Recognition and treatment. West $\mathcal{f}$ Med 1993; 159: 286-300.

5 Smythe JF, Copel JA, Kleinman CS. Outcome of prenatally detected cardiac malformations. $A m$ f Cardiol 1992; 69: 1471-4.

\section{Cerebral autoregulation of preterm neonates - a non-linear control system?}

EDITOR,-We read with interest the detailed paper of Zernikow et al on cerebral autoregulation of preterm neonates. ${ }^{1}$ However we would caution against the use of the term autoregulation. This term implies maintaining a constant cerebral perfusion in the face of a changing cerebral perfusion pressure. ${ }^{2}$ The slow wave cycles we, and others, have described in the cerebral blood flow velocity values occur independently of blood pressure and are indices of velocity and not flow. ${ }^{3}$ They undoubtedly reflect some underlying physiological control but it would be incorrect to describe this as autoregulation.

M Y ANTHONY Fohn Radcliffe Hospital,
M I LEVENE

Department of Child Health, Leeds General Infirmary,
Leeds LS2 $9 N S$

1 Zernikow B, Michel E, Kohlmann G, Steck J, Schmitt RM, Jorch G. Cerebral autoregulation of preterm neonates - a non-linear control of preterm neonates - a non-linear con
system? Arch Dis Child 1994; 70: F166-73.

2 Anthony MY, Evans DH, Levene MI. Neonatal cerebral blood flow velocity responses to changes in posture. Arch Dis Child 1993; 69 304-8.

3 Anthony MY, Evans DH, Levene MI. Cyclical variations in cerebral blood flow velocity. Arch Dis Child 1991; 66: 12-6

Professor forch and coauthors comment:

We use the term 'autoregulation' in a more general meaning to describe the autonomous regulation of cerebral haemodynamics. It addresses the complexity of regulation, is not limited to the mean arterial blood pressurecerebral blood flow autoregulation relationship, and the regulative result is not necessarily the constancy of cerebral blood flow. ${ }^{1}$ If this was not clear from our paper, we thank Dr Anthony and Professor Levene for their comment.

1 Menke J, Michel E, Rabe H, et al. Simultaneous influence of blood flow pressure, pCO2, and pO2 on cerebral blood flow velocity in preterm infants of less than 33 weeks' gestation. Pediat Res 1993; 34: 173-7. 